Syntax Literate: Jurnal Ilmiah Indonesia p-ISSN: 2541-0849

e-ISSN: 2548-1398

Vol. 6, No. 12, Desember 2021

\title{
DESAIN PENGEMBANGAN KURIKULUM PRODI TEOLOGI DALAM UPAYA MENGHASILKAN LULUSAN BERDASARKAN KEBUTUHAN JEMAAT
}

\section{Haposan Silalahi, Maria Widiastuti, Agnes Novianti Permata Sari, Damayanti Nababan}

Institut Agama Kristen Negeri Tarutung, Indonesia

Email: hanslahi.hs@gmail.com, mariawidiastutitarigan@gmail.com, agnesnoviantih@gmail.com, nababanyanti02@gmail.com

\begin{abstract}
Abstrak
Dalam upaya penggembangan Institut Agama Kristen Negeri Tarutung, prodi Teologi berupaya memberikan terobosan baru yang mengacu pada kurikulum KKNI dan Merdeka belajar dan Kampus merdeka. Sehingga prodi teologi mampu menghasilkan lulusan-lusan yang sesuai dengan kebutuhan masyarakat, yang dapat berinovasi dan mengatualisasikan diri. Dengan demikian pengembangan kurikulum menjadi sebuah acuan yang sangat penting. Tujuan penelitian adalah untuk memberikan sumbangsih dalam upaya pengembangan kurikulum prodi teologi berbasis kebutuhan jemaat. Metode pengumpulan data yang di gunakan dalam penelitian ini adalah metode observasi dan wawancara. Metode pengumpulan data yang di gunakan dalam penelitian ini adalah metode observasi dan wawancara. . Beberapa usulan para pengguna dan alumni dalam pengembangan kurikulum prodi Teologi berbasis Kebutuhan Jemaat, antara lain pertama Kearifan Lokal, Teologi Feminisme, (secara khusus tentang Perempuan dan kekerasan), Teologi Kerja dan Kewirausahaan. Para alumni dan pengguna mengatakan bahwa ketiga mata kuliah tersebut perlu menjadi bagian dari proses pembelajaran di prodi teologi sehingga lulusannya kompeten dalam menyikapi persolan di tengah-tengah masyarakat.
\end{abstract}

Kata Kunci: kurikulum; prodi teologi; kebutuhan jemaat

\section{Abstract}

In an effort to develop the Tarutung State Christian Institute, the Theology Study Program seeks to provide new breakthroughs that refer to the KKNI curriculum and Independent Learning and Independent Campus. So that the theology study program is able to produce graduates who are in accordance with the needs of the community, who can innovate and actualize themselves. Thus curriculum development becomes a very important reference. The purpose of this research is to contribute to the development of the theology study program curriculum based on the needs of the congregation. The data collection method used in this research is the method of observation and interviews. The data collection method used in this research is the method of observation and interviews. Some suggestions from users and alumni in developing the curriculum of the Theology Study Program based on Congregational Needs, among others, first are Local Wisdom, Theology of Feminism, (specifically on Women and violence), Work Theology and

$\begin{array}{ll}\text { How to cite: } & \text { Silalahi. H., Maria Widiastuti, Agnes Novianti Permata Sari, Damayanti Nababan (2021) Desain } \\ & \text { Pengembangan Kurikulum Prodi Teologi dalam Upaya Menghasilkan Lulusan Berdasarkan Kebutuhan Jemaat. } \\ & \text { Syntax Literate: Jurnal Ilmiah Indonesia, 6(12). http://dx.doi.org/10.36418/Syntax-Literate.v6i12.5044 } \\ \text { E-ISSN: } & \text { 2548-1398 } \\ \text { Published by: } & \text { Ridwan Institute }\end{array}$


Entrepreneurship. Alumni and users said that the three courses need to be part of the learning process in theology study program so that graduates are competent in responding to problems in society.

Keywords: curriculum; theological study; the needs of the congregation

Received: 2021-11-20; Accepted: 2021-12-05; Published: 2021-12-20

\section{Pendahuluan}

Dunia pendidikan saat ini dihadapkan pada tuntutan untuk menghasilkan lulusan berkualitas tinggi yang mampu bersaing ketat pada era globalisasi. Lulusan yang dikehendaki adalah lulusan yang di samping menguasai ilmu pengetahuan, memiliki keterampilan, kreativitas, dan daya saing, juga memiliki bekal agama, moral, dan akhlak mulia. Pendidikan yang tidak dapat melakukan fungsi itu dengan sendirinya ditinggalkan oleh masyarakat. Keadaan itu pada gilirannya akan memaksa dunia pendidikan untuk terus peka membaca kecenderungan masyarakat dan tuntutan zaman serta mengantisipasinya dengan terus memperbaiki berbagai komponen terkait di dalamnya. Dari hal tersebut maka peningkatan kualitas pendidikan harus dilakukan secara terus menerus dan harus berkesinambungan. Menurut Quisumbing (Kartowagiran, 2010), kualitas pendidikan adalah proses yang dinamik, tidak statis dan bukan berupa produk akhir. Tingkat kualitas pendidikan jika diamati harus dilihat oleh tuntutan masyarakat dan perkembangan ilmu pengetahuan dan teknologi serta seni.

Kualitas pendidikan dipengaruhi oleh banyak faktor, antara lain: kualitas peserta didik, kualitas pendidik, kualitas lingkungan belajar, kualitas kurikulum, dan kualitas proses pembelajaran. Oleh karena itu, sudah sewajarnyalah bila dalam rangka meningkatkan kualitas pendidikan melalui peningkatan kualitas kurikulum maka perlu dilakukan evaluasi kurikulum (Kartowagiran, 2010).

Kurikulum lembaga pendidikan merupakan instrumen strategis untuk pengembangan kualitas sumber daya manusia baik jangka pendek maupun jangka panjang. Karena begitu pentingnya fungsi dan peran kurikulum, maka semua pihak yang terlibat di dalamnya harus memiliki pengetahuan yang memadahi tentang kurikulum seperti pimpinan lembaga pendidikan, guru, dosen, dan sebagainya. Dalam rangka meningkatkan mutu pendidikan secara nasional dan mutu sumber daya manusia, kurikulum perlu di evaluasi dan dikembangkan. Seiring dengan perkembagan Ilmu Pengetahuan, Teknologi, dan Seni, pemerintah selalu melakukan berbagai pembenahan dan perbaikan kurikulum pendidikan agar secara lentur dapat bergerak cepat sejalan dengan tuntutan dunia kerja serta tuntutan kehidupan masyarakat yang dinamis.

Istilah kurikulum berasal dari bahasa Latin. Sebuah kata benda yang berasal dari kata kerja currere yang berarti lari. Secara harafiah kurikulum adalah jalur untuk berlari atau arena balap (Lauterboom, 2020). Kata Kurikulum secara harafiah berarti "racecourse" (gelanggang Pacuan kuda) secara tradisional gelanggang dianggap badan dari sisi yang dicakup siswa dalam perkembangan pendidikannya, istilah ini juga berarti kegiatan siswa pada saat ia memulai beragam pengalaman yang melibatkan isi. 
Kurikulum dalam pandangan luas dipahami bahwa kurikulum tidak hanya dibatasi pada mata pelajaran saja tetapi mencakup perencanaan pengalaman belajar, program sebuah lembaga pendidikan yang diwujudkan dalam sebuah dokumen serta hasil dari implementasi dokumen yang telah disusun sebagaimana pendapat Murray Print. Ia menyatakan, "kurikulum meliputi: planned learning experiences; offered within an educational institution/program;represented as a document; and includes experiences resulting fom implementing that document" (Bahrissalim dan \& Fauzan, 2018). Menurut (Lebar, E, 2006) dalam orentasi alkitabiah "kurikulum" sebagai kegiatankegiatan yang berkaitan dengan misi berotoritas yang dibimbing atau dilaksanakan oleh kepemimpinan Kristen agar dapat membawa siswa kepada kedewasaan didalam Kristus.

Setiap kurikulum yang telah dilaksanakan dalam pembelajaran harus di evaluasi guna melihat hasil yang tercapai dalam pembelajaran. Evaluasi merupakan suatu proses yang direncanakan untuk memperoleh informasi tentang pencapaian suatu tujuan. Senada dengan hal ini, Mahrens \& Lehmann (Kartowagiran, 2010) menyatakan "evaluation is the process of delineating, obtaining, and providing useful information for judging decision alternatives". Evaluasi merupakan suatu proses merencanakan, memperoleh, dan menyediakan informasi yang sangat diperlukan untuk membuat keputusan. Sedangkan evaluasi menurut (Rosyada, 2004) adalah sebuah proses yang sistematis untuk melakukan pengumpulan, analisis dan interpretasi terhadap informasi yang dapat menetapkan tingkatan pencapaian tujuan belajar dari pembalajar.

Evaluasi kurikulum memegang peranan penting dalam proses pendidikan dengan tujuan mengetahui hingga manakah mahasiswa mencapai kemajuan ke arah tujuan yang telah ditentukan. Namun dalam hal evaluasi kurikulum harus dilaksanakan dengan sistematis yang sesuai dengan konsep dasar evaluasi kurikulum, sehingga hasil evaluasi kurikulum sesuai dengan kebutuhan dan kemampuan pelaku-pelaku dunia pendidikan dan masyarakat secara umum (Hamdi, 2020). Evaluasi kurikulum dilakukan untuk memproses, mempertimbangkan dan memberi nilai serta arti terhadap tujuan, isi, hasil pemebelajaran yang menyeluruh dan saling keterkaitan yang mana hal ini diusahakan oleh pendidik yang di rancang untuk mahsiswa baik di dalam kelas maupun diluar kelas.

Tujuan evaluasi kurikulum yaitu mengungkapkan proses pelaksanaan kurikulum secara keseluruhan, ditinjau dari berbagai aspek. Dalam hal ini menurut Ibrahim (Hamdi, 2020) diadakan evaluasi kurikulum dimaksudkan untuk keperluan berikut:

a. Perbaikan Program Peranan evaluasi, yaitu lebih bersifat kontruktif, informasi hasil evaluasi dijadikan masukan perbaikan yang diperlukan di dalam program kurikulum yang sedang dikembangkan. Evaluasi kurikulum dipandang sebagai proses dan hasil yang relevan untuk dijadikan acuan pengembangan kurikulum yang akan dilaksanakan.

b. Pertanggungjawaban Kepada Berbagai Pihak Evaluasi kurikulum menjadi bentuk laporan yang harus dipertanggung jawaban dari pengembang kurikulum kepada pihak-pihak yang bersangkutan, diantaranya: Pemerintah, orang tua, pelaksana satuan pendidikan, masyarakat, dan semua pihak yang secara langsung maupun tidak langsung ikut serta dalam pengembangan kurikulum yang bersangkutan. 
c. Penentuan Tindak Lanjut Hasil Pengembangan Tindak lanjut hasil pengembang kurikulum dapat berbentuk jawaban atas dua kemungkinan pertanyaan. Pertama, apakah kurikulum baru tersebut akan atau tidak akan disebarluaskan ke dalam sistem yang ada? Kedua, dalam kondisi yang bagaimana dan dengan cara yang bagaimana pula kurikulum baru tersebut akan disebarluaskan ke dalam sistem yang ada?

Tujuan evaluasi kurikulum dapat melihat bagaimana kurikulum itu berjalan, apakah berdampak baik atau tidak bagi alumni, mahasiswa dan pengguna alumni sehingga dari hasil evaluasi tersebut maka dosen yang sebagai pendidik dapat mengembangkan kurikulum yang dipegang dan menjadikan kurikulum terebut berdampak kepada tujuan pendidikan dari program studi yang dijalani mahasiswa. Dalam hal ini pemerintah juga menekankan dalam Peraturan Pemerintah No. 17 Tahun 2010 Pasal 97 bahwa kurikulum perguruan tinggi dikembangkan dan dilaksanakan berbasis kompetensi. Kurikulum tingkat satuan pendidikan untuk setiap program studi di perguruan tinggi dikembangkan dan ditetapkan oleh tiap-tiap perguruan tinggi dengan mengacu pada Standar Nasional Pendidikan (Suwandi, 2014). Secara terminologi "Pengembangan" ialah adalah kegiatan yang menghasilkan suatu alat atau cara yang baru, dimana selama kegiatan menghasilkan suatu alat atau cara baru, dimana selama kegiatan tersebut penilaian dan penyempurnaan terhadap alat dan cara terus dilakukan (dikembangkan) (Sutopo, 2003).

Pengembangan kurikulum diartikan sebagai suatu proses, dalam proses pengembangan ada beberapa langkah yang harus dilakkan: Pertama, Merumuskan "Profil Lulusan", yang menggambarkan profil lulusan yang akan dihasilkan oleh Program Studi. Rumusan Kedua, Menetapkan dan menentukan "capaian pembelajaran atau kompetensi". Capaian pembelajaran" kemampuan yang diperoleh melalu internalisasi pengetahuan, sikap, keterampilan, kompetensi dan akumulasi pengalaman kerja”. Ketiga, Memilih dan menetapkan "bahan kajian" yang akan dipelajari. Bahan kajian tersebut dapat dikelompokkan, umpamanya kepada kelompok: inti keilmuan Program Studi (PRODI), Ilmu Pengetahuan dan Teknologi pendukung, Ilmu Pengetahuan dan Teknologi pelengkap, Ilmu Pengetahuan dan Teknologi yang dikembangkan, Iptek masa depan, dan Iptek sebagai penciri perguruan tingi. Keempat, Menetapkan mata kuliah yang akan diajarkan dalam satu program studi (Teologi, 2019). Dari adanya pengembangan maka kita bisa mendesain kurikulum Teologi agar menjadi pengalaman belajar dan perencanaan pembelajaran bagi prodi Teologi.

Desain kurikulum merujuk pada penyusunan atau organisasi elemen-elemen kurikulum yang menyangkut tujuan umum dan khusus, isi program, kegiatan atau pemberian pengalaman belajar dan evaluasi (Sundayana, 2017). Karena desain adalah rancangan, pola atau model, berarti menyusun rancangan atau menyusun model kurikulum sesuai dengan misi dan visi sekolah (Rusman, 2018). Jadi desain kurikulum dapat dikatakan proses pengorganisasian komponen kurikulum yang mencakup tujuan, isi, metode mengajar, evaluasi penilaian hasil belajar yang dijadikan paduan atau pedoman dalam melaksanakan aktivitas akademik. 
IAKN Tarutung merupakan Perguruan Tinggi yang berada di bawah naungan Kementerian Agama mewajibkan jurusan-jurusan di dalamnya menyelenggarakan mata kuliah teologi kekristenan untuk diintegrasi-interkoneksikan dengan kelimuan-keilmuan pada prodi teologi. Prodi Teologi merupakan salah satu prodi yang dimiliki IAKN Tarutung. Prodi tersebut berada di Fakultas Ilmu Teologi di IAKN Tarutung. Persaingan semakin sengit sehingga kualitas unggul berupa kompetensi dan pengalaman yang dimiliki seseorang menjadi prioritas. Untuk membekali lulusannya dalam menghadapi tantangan global tersebut, prodi teologi berusaha meningkatkan mutu atau kualitas lulusannya, salah satunya dengan mengembangkan kurikulum secara berkala. Visi (Teologi, 2019) prodi Teologi IAKN Tarutung adalah menjadi prodi teologi yang menghasilkan lulusan berintegritas, berwawasan ekumenis terampil melayani di gereja dan masyarakat. Sedangkan misi (Teologi, 2019) prodi Teologi di IAKN Tarutung adalah: 1) Menyelenggarakan pendidikan dan pengajaran sebagai bagian dari pengembangan ilmu pada bidang Teologi, 2) Melaksanakan penelitian dalam pengembangan ilmu pengetahuan pada bidang Teologi, 3) Menyelenggarakan pengabdian kepada masyarakat sebagai bagian dari upaya untuk mengimplementasikan ilmu Teologi di tengah gereja dan masyarakat. Dari visi dan misi program studi Teologi maka sebagai tim pengajar harus mampu melaksanakan pembelajaran sesuai dengan tuntutan lulusan program studi Teologi.

Dari visi dan misi yang kita lihat, masih ada Kendala dimana visi dan misi belum terlaksana dengan baik dikarenakan mata kuliah yang ada dalam kurikulum prodi Teologi belum terintegrasi dengan visi dan misi prodi Teologi, hal ini dilihat dari evaluasi kurikulum yang telah dilaksanakan. Sehingga peniliti berupaya menghasilkan konsep mata kuliah yang sesuai dengan visi dan misi prodi teologi yaitu berbasis kebutuhan jemaat.

Penelitian ini bertujuan untuk mengetahui mekanisme atau langkah-langkah yang ditempuh dalam penyusunan Desain Kurikulum Pendidikan Tinggi mengacu KKNI di Prodi Teologi di IAKN Tarutung yang melibatkan banyak pihak dan melalui proses yang cukup panjang, kemudian kurikulum di evaluasi serta dikembangkan sesuai dengan kebutuhan alumni, mahasiswa dan kebutuhan jemaat. Selanjutnya, peneliti juga berupaya mencari tahu kesesuaian langkah-langkah yang telah ditempuh oleh tim kurikulum Prodi Teologi di IAKN Tarutung ditinjau dari panduan penyusunan Kurikulum Pendidikan Tinggi mengacu KKNI yang dibuat oleh tim dari Direktorat Jenderal Pendidikan Tinggi. Peninjaun kurikulum sebagai tindakan untuk menjawab kebutuhan dunia kerja, dan lokakarya peninjaun kurikulum yang dilaksanakan oleh program studi Pendidikan Teologi saat ini adalah sebagai upaya untuk menciptakan lulusan yang kompeten dibidangnya. 


\section{Metode Penelitian}

Penelitian ini adalah penelitian deskriptif kualitatif, yaitu data yang dikumpulkan berbentuk kata-kata, gambar, bukan angka-angka. Menurut (Sugiyono, 2017) metode kualitatif adalah metode penelitian yang lebih menekankan makna. Sementara itu, penelitian deskriptif adalah suatu bentuk penelitian yang ditunjukkan untuk mendeskripsikan atau menggambarkan fenomena-fenomena yang ada, baik fenomena alamiah maupun rekayasa manusia.

Metode pengumpulan data yang di gunakan dalam penelitian ini adalah metode observasi dan wawancara. Observasi dan wawancara digunakan mampu untuk menganalisis data-data yang telah didapat dari informan dengan mengedepankan kedalaman infomasi sehingga penelitian ini bisa akurat dan dapat dipertanggungjawabkan. (Bungin, 2012) mengatakan bahwa: "Observasi digunakan untuk melakukan pengamatan, pencatatan secara sistematik kejadian-kejadian, perilaku, objek-objek, yang dilihat dan hal-hal lain yang diperlukan dalam mendukung data untuk penelitian yang sedang dilakukan. Melalui pengamatan langsung peneliti akan mendapatkan data-data ataupun informasi tentang mekanisme atau langkah-langkah yang ditempuh dalam penyusunan Kurikulum Pendidikan Tinggi mengacu KKNI di Prodi Teologi di IAKN Tarutung yang melibatkan pihak alumni dan pengguna. Dengan menggunakan teknik pengamatan langsung peneliti dapat merasakan langsung, serta berada dalam "aktivitas objek-objek yang sedang diamati dan sedang di teliti".

Observasi sangat penting dilakukan dalam mengumpulkan data penelitian. Dengan melakukan observasi peneliti dapat mengetahui Alat utama yang akan dipakai dalam mengumpulkan data. Dengan melakukan observasi peneliti dapat mengetahui apa saja yang diingikan alumni dan pengguna kurikulum serta dampak yang mereka rasakan. Berdasarkan hasil observasi kemudian peneliti mengajukan pertanyaanpertanyaan seputar apa yang dapat di evalusai dan dikembangkan dari kurikulum yang sudah ada. Sedangkan wawancara menurut (Moleong, 2013) adalah percakapan yang dilakukan dua orang yaitu pewawancara (interviewer) yang memberikan pertanyaan dan yang diwawancarai (interviewee) yang memberikan informasi atau jawaban atas pertanyaan tersebut.

Wawancara yang dilakukan dalam penelitian ini adalah wawancara mendalam, yaitu penulis dan informan berinteraksi satu sama lain dalam waktu yang relatif lama sehingga penulis dapat membangun rapport dengan informan. Adapun jenis wawancara yang penulis lakukan dalam penelitian ini adalah wawancara langsung atau interview langsung dan wawancara secara tidak langsung melalui aplikasi Google fom, WA, email dan lewat telepon. Model wawancara yang digunakan adalah wawancara mendalam (indepht interview) dengan wawancara yang dilakukan secara tuntas, terfokus pada data yang diperlukan.

Teknik dalam pemilihan informan penelitian menggunakan purposive sampling. Menurut (Sugiyono, 2017) purposive sampling adalah teknik yang digunakan untuk menentukan sumber informan yang sesuai dengan kriteria terpilih dan relevan dengan permasalahan penelitian. 
Analisis data dalam penelitian merupakan suatu pandangan mengenai penulis untuk bersikap objektif terhadap data yang diperoleh dilapangan. Keseluruhan data yang diperoleh dari hasil penelitian lapangan tersebut akan diteliti kembali atau diedit ulang, pada akhirnya kegiatan ini bertujuan untuk memeriksa kembali kelengkapan data lapangan dan hasil wawancara.

Analisis data menurut (Sugiyono, 2017) adalah proses mencari dan menyusun secara sistematis data yang diperoleh dari hasil wawancara, catatan lapangan, dan bahan-bahan lain, sehingga dapat mudah dipahami, dan temuannya dapat diinformasikan kepada orang lain. Analisis data dilakukan dengan mengorganisasikan data menjabarkannya kedalam unit-unit, melakukan sintesa, menyusun kedalam pola, memilih mana yang penting dan yang akan dipelajari dan membuat kesimpulan yang dapat diceritakan kepada orang lain. Untuk mengelola data yang didapatkan dari penelitian ini, data akan dianalisis dengan menggunakan teknik deskriptif yaitu teknik yang digunakan untuk mendeskripsikan atau menggambarkan masalah yang diteliti secara apa adanya dengan menggunakan uraian dan bukan dalam bentuk angka-angka atau statistik. (Sugiyono, 2017) membagi proses analisis data ke dalam tiga komponen utama yang meliputi reduksi data, penyajian data, dan penarikan simpulan atau verifikasi data. Ketiga komponen tersebut merupakan bagian dari proses analisis yang saling berkaitan antara satu dengan yang lain. Analisis data dilakukan untuk menentukan hasil akhir dari penelitian, yang kemudian ditunjang oleh teori kebudayaan guna mendapatkan hasil penelitian yang baik.

\section{Hasil dan Pembahasan}

Kurikulum merupakan salah satu komponen penting dalam pendidikan untuk jenjang pendidikan dasar sampai pendidikan tinggi. Dalam implentasinya terdapat masalah-masalah yang berkaitan dengan kurikulum sehingga menjadi kendala dalam tercapainya tujuan pendidikan. Masalah-masalah tersebut antara lain: pertama, peserta didik terbebani dengan penguasaan materi dan pendidik terbebani dengan pencapaian target maksimal dalam pengajaran. Hal ini berdampak pada terbatasnya peserta didik dalam mengembangkan potensinya dan pendidik dalam mengembangkan kreatifitasnya dalam pengajaran. Kedua, kurikulum cenderung berganti sistem dan nama yang diterapkan dalam proses Pendidikan, dalam kurun waktu 5 tahun terakhir kurikulum prodi teologi IAKN Tarutung juga telah mengalami perubahan sebanyak 2 kali.

Dari masalah-masalah yang ditemukan perlu adanya solusi untuk terwujudnya pendidikan yang berkualitas yaitu pengembangan kurikulum nasional yang diintegrasikan dengan kurikulum internal (lokal lembaga), seperti pengembangan kurikulum Prodi Teologi yang disusun berdasarkan peraturan pemerintah dan otonomi lembaga dalam mengembangkan materi-materi perkuliahan.

Hasil pengumpulan informasi diperoleh kesimpulan bahwa Pertama, desain kurikulum Prodi Teologi merupakan kurikulum yang ditetapkan pemerintah yaitu KKNI dan mengintegrasikannya dengan kurikulum Prodi Teologi yang memiliki keunggulan muatan kurikulumnya pada materi yang berbasis Alkitabiah yang menciptakan suasana 
akademik yang interdenominasi. Kedua, berdasarkan wawancara yang kami lakukan terhadap pengguna alumni dan alumni yang sebagian besar sebagai Pendeta di berbagai denominasi sehingga kurikulum yang ditawarkan di prodi teologi sudah mendukung dalam penggembalaan, tetapi ada bebrapa hal yang bisa disesuaikan kondisi jemaat pada umumnya. Perlu ditinjau ulang sesuai dengan perkembangan yang ada di jemaat secara umum.

\section{A. Desain Produk}

Desain kurikulum Prodi Teologi merupakan suatu proses penyusunan komponen kurikulum yang mencakup tujuan pembelajaran, isi materi, tujuan pengajaran, strategi pembelajaran, dan evaluasi hasil belajar yang dijadikan sebagai pedoman bagi civitas akademika Prodi teologi dalam melaksanakan kegiatan akademik perkuliahan. Desain Kurikulum prodi teologi merupakan kurikulum yang didesain dan dirancang dengan mengintegrasikan kurikulum anjuran pemerintah KKNI dan Merdeka belajar.

Demi kemajuan pendidikan prodi Teologi dan memenuhi kebutuhan masyarakat perlu rekontruksi dan pengembangan kurikulum guna perbaikan pendidikan ke depan yang diharapkan mampu merekonstruksi dengan pendekatan yang sesuai dengan zaman milenial ini. Berasaskan perkembangan ilmu pengetahuan dan teknologi diperlukannya upaya-upaya dalam pemanfaatan teknologi untuk proses pembelajaran. Hal ini dilakukan dengan tujuan terciptanya pembelajaran yang aktif, terampil, dan up to date serta efisien. Dengan dikeluarkannya kebijakan Menteri Pendidikan dan Kebudayaan tentang Merdeka Belajar, maka secara otomatis hal ini sangat berdampak pada kurikulum setiap Program Studi di setiap Kampus. Sehingga dalam mengadapatasikan Kebijakan Merdeka Belajar, maka perlu Desain pengembangan Kurikulum Program Studi Teologi di IAKN Tarutung.

Dalam analisis pendahuluan, berkaitan dengan kebijakan Merdeka Belajar, produk yang dikembangkan pada penelitian ini yaitu kurikulum Program Studi Teologi berbasis Kebutuhan Jemaat. Kurikulum muatan berbasis Kebutuhan Jemaat ini diharapkan nantinya dapat diterapkan pada seluruh program studi yang ada di IAKN Tarutung.

Dalam tahap pengembangan produk, peneliti menetapkan pemetaan mata kuliah dalam bentuk Distribusi Mata Kuliah disertai dengan Deskripsi Mata Kuliah dalam pembelajaran prodi Teologi di bawah naungan Fakultas Ilmu Teologi (FIT) IAKN Tarutung. Beberapa usulan para pengguna dan alumni dalam pengembangan kurikulum prodi Teologi berbasis Kebutuhan Jemaat, antara lain:

1. Kearifan Lokal

Matakuliah ini merupakan matakuliah yang berfungsi sebagai media pengembangan bagi eksplorasi pemikiran-pemikiran teologi yang bernilai luhur serta media pengkajian secara kritis prospek eksistensi pemikiran lokal tersebut sebagai akibat perkembangan budaya dan pengaruh global umumnya. Mahasiswa mampu mengkritisi secara teologis eksistensi kearifan lokal budaya pada umumnya, dan budaya Nusantara pada khususnya. 
2. Teologi Feminisme, (secara khusus tentang Perempuan dan kekerasan).

Mata kuliah ini bersisi bahasan tentang konsep gender dan seks, teori gender, sejarah gerakan perempuan di Indonesia/Batak, feminisme konsep dan sejarah perkembangannya, metode penelitian berwawasan gender, analisis gender, gender dalam konteks daerah batak, nasional dan internasional, gender dari perspektif agama, gender dalam Kekristenan, hak-hak poliik perempuan dalam Kekristenan, Teologi dan Hak Reproduksi perempuan, Kekerasan terhadap perempuan dan Kristen, gender dalam pendidikan, dan Trafficking.

3. Teologi Kerja dan Kewirausahaan

Program ini bertujuan mengembangkan pemahaman dan kesadaran tentang hakikat entrepreneurship yang mencakup konsep dasar, karakteristik, serta tujuanpembelajaran entrepreneurship. Mahasiswa mampu menginternalisasi nilai dan sikap yang terkandung dalam entrepreneurship, seperti etos bekerja, motif berprestasi, kemandirian, kreativitas, keterampilan pengambilan keputusan, dan sebagainya. Mengembangkan employability skills dalam diri mahasiswa sebagai prasyarat dasar terbentuknya jiwa dan etos entrepreneurship (project learning). Mahasiswa dapat mendiseminasikan karakteristik dan etos entrepreneurship secara meluas melalui jalur pendidikan formal, informal, maupun nonformal.

\section{B. Validasi Ahli}

Berdasarkan hasil penilaian validator ahli kurikulum mengenai desain kurikulum berbasis Merdeka Belajar pada program studi Teologi di Fakultas Ilmu Teologi IAKN Tarutung yang dikembangkan pada penelitian ini layak digunakan pada pembelajaran Prodi Teologi IAKN Tarutung. Penelitian ini dianalisis dengan analaisis kulitatif dimana kesimpulan yang ada didukung oleh bukti-bukti yang valid sehingga menghasilkan kesimpulan dan hasil akhir yang kredibel.

\section{Kesimpulan}

Pengembangan sebuah kurikulum perlu dilandasi pada hakikat ilmu pengetahuan kehidupan dengan memperhatikan prinsip bahwa kurikulum itu harus relevan, berorientasi pada tujuan, efesien, efektif, kontinuitas, fleksibel, seimbang terpadu dan memperhatikan mutu. Kurikulum yang melihat lulusan berdasarkan kebutuhan jemaat diharapkan dapat menjadi jawaban atas kebutuhan dunia kerja berorientasi pelayanan berjemaat. Kebijakan Merdeka Belajar merupakan wujud pembelajaran di perguruan tinggi yang otonom dan fleksibel sehingga tercipta kultur belajar yang inovatif tidak mengekang dan sesuai dengan kebutuhan mahasiswa. 
Desain Pengembangan Kurikulum Prodi Teologi dalam Upaya Menghasilkan Lulusan Berdasarkan Kebutuhan Jemaat

\section{BIBLIOGRAFI}

Bahrissalim dan, \& Fauzan. (2018). Evaluasi Kurikulum Pelatihan dalam Meningkatkan Kompetensi Pedagogik Guru PAI di Balai Diklat Keagamaan Jakarta. 13(1), 2552. Google Scholar

Bungin, Burhan. (2012). Analisis Data Penelitian Kualitatif: Wancana dan Teoritis Penafsiran. Jakarta: Raja Grafindo Persada. Google Scholar

Hamdi, Mohammad Mustaf. (2020). Evalusi Kurikulum Pendidikan. Intizam, Jurnal Manajemen Pendidikan Islam, 4(1), 66-75. Google Scholar

Kartowagiran, Badrun. (2010). Evaluasi kurikulum. Jurnal Penelitian Dan Evaluasi Pendidikan, 19(1), 1-9. Google Scholar

Lauterboom, Mariska. (2020). Dekolonialisasi Pendidikan Agama Kristen di Indonesia. Indonesian Journal of Theology, 7(1), 88-110. https://doi.org/10.46567/ijt.v7i1.8 Google Scholar

Lebar, E, Loise. (2006). Education That Is Christian. Malang: Gandum Mas. Google Scholar

Moleong, Lexy J. (2013). Metode Penelitian Kualitatif, Bandung: Remaja Rosdakarya. Mosal. Google Scholar

Rosyada, Dede. (2004). Paradigma pendidikan demokratis: sebuah model pelibatan masyarakat dalam penyelenggaraan pendidikan (cetakan ke). Jakarta: Kencana. Google Scholar

Rusman. (2018). Manajemen Kurikulum. Jakarta: Rajawali Pers.

Sugiyono, P. D. (2017). Metode Penelitian Bisnis: Pendekatan Kuantitatif, Kualitatif, Kombinasi, dan R\&D. Penerbit CV. Alfabeta: Bandung. Google Scholar

Sundayana, Wahyu. (2017). Telaah kurikulum \& perencanaan pembelajaran : panduan bagi calon guru dan guru dalam merancang pembelajaran yang sistematis. Jakarta: Erlangga. Google Scholar

Sutopo, Hendyat. (2003). Pembinaan dan Pengembangan Kurikulum Sebagai Substansi Problem Administrasi Pendidikan. Jakarta: Bumi Aksara.

Suwandi, Sarwiji. (2014). Pengembangan Kurikulum Program Program Doktor Ilmu Pendidikan : Pendidikan Berbasis Capaian. Seminar Nasional. Google Scholar

Teologi, Tim Dosen. (2019). Buku Pedoman Program Studi Teologi Fakultas Ilmu Teologi IAKN Tarutung. Tarutung.

\section{Copyright holder:}


Haposan Silalahi, Maria Widiastuti, Agnes Novianti Permata Sari, Damayanti Nababan

Haposan Silalahi, Maria Widiastuti, Agnes Novianti Permata Sari, Damayanti Nababan (2021)

First publication right:

Syntax Literate: Jurnal Ilmiah Indonesia

This article is licensed under:

(c) (7) (2) 